\title{
The Importance of Being Discovered: The Werner Von Boltenstern Shanghai Photograph and Negative Collection
}

\author{
Melanie Hubbard \\ William H. Hannon Library, Loyola Marymount University
}

\begin{abstract}
The Werner von Boltenstern Shanghai Photograph and Negative Collection, housed in Loyola Marymount University's William H. Hannon Library, is a series of photographs of 1930s-1940s Shanghai taken by Werner von Boltenstern. The images capture a time and place at a crossroads of culture and history. World War II and the Second Sino-Japanese War were raging and the city, a trade center populated by numerous peoples, including Chinese citizens, British, French, and American nationals, Sephardic and Russian Jews, and the occupying Japanese military, was receiving an influx of European Jews fleeing Nazi Europe. The rediscovery of this collection (it sat unused for many years) led to its digitization, a successful crowdsourcing effort to gather more metadata, and the incorporation of the collection into an LMU Literature of the Holocaust class digital project. Through these endeavors, the library has increased its understanding of the collection's historical value, in particular as it relates to Holocaust studies and Jewish studies more broadly.
\end{abstract}

Keywords: Holocaust, Shanghai Jewish Refugees, Photography, China, Digitization, Digital Humanities

\section{A Discovery}

Archive and special collections vaults are full of "undiscovered" treasures: objects that have yet to be processed or even once processed, have since seen little light of day. One such treasure is the Werner von Boltenstern Shanghai Photograph and Negative Collection (Shanghai Collection, see at digitalcollections.lmu.edu). Once part of a larger collection, the photographic materials had been removed, rehoused and intriguingly relabeled "Shanghai Jewish Community." That label piqued my curiosity and sparked a desire to research the collection and its subject matter. What began as a personal interest led to the collection's digitization, a crowdsourcing effort to gather more metadata, and the incorporation of the collection into several curricula at Loyola Marymount University (LMU). 


\section{THE HISTORY}

Werner von Boltenstern (1904-1974) gave the Shanghai Collection, a series of photographic negatives and prints, to LMU when he donated his enormous postcard collection to the university in the late 1960s. ${ }^{1}$ The photographic materials had been filed neatly among the postcards and once found, were removed and rehoused in acid-free envelopes, stored in acid-free boxes, and labeled "Shanghai Jewish Community." The photographs, taken during von Boltenstern's nine-year long travels across the globe capture 1937-1949 Shanghai, a booming trade center and home to a diverse population. In addition to its numerous Chinese communities, the city was populated by British, French, and American nationals, the Japanese military - the second Sino-Japanese War was underway - and Jewish communities, which included Sephardic and Russian Jews as well as newly arriving European Jews seeking refuge from Nazi Germany.

Von Boltenstern left his native Germany in the early 1930s to travel the world. He paid his way by selling his photographs to postcard and calendar publishers. According to his daughter, Erica, he used to say, with his usual tinge of humor and hyperbole, that there were two ways to earn money while traveling, "One was haircutting and one was photography" (von Boltenstern 2014); ${ }^{2}$ fortunately, he chose the latter. Von Boltenstern's journey took him across Europe, into Africa, and through Asia. While in Outer Mongolia preparing a set of postcards for the Chinese Government, he received a letter from his mother telling him that war was inevitable and not to

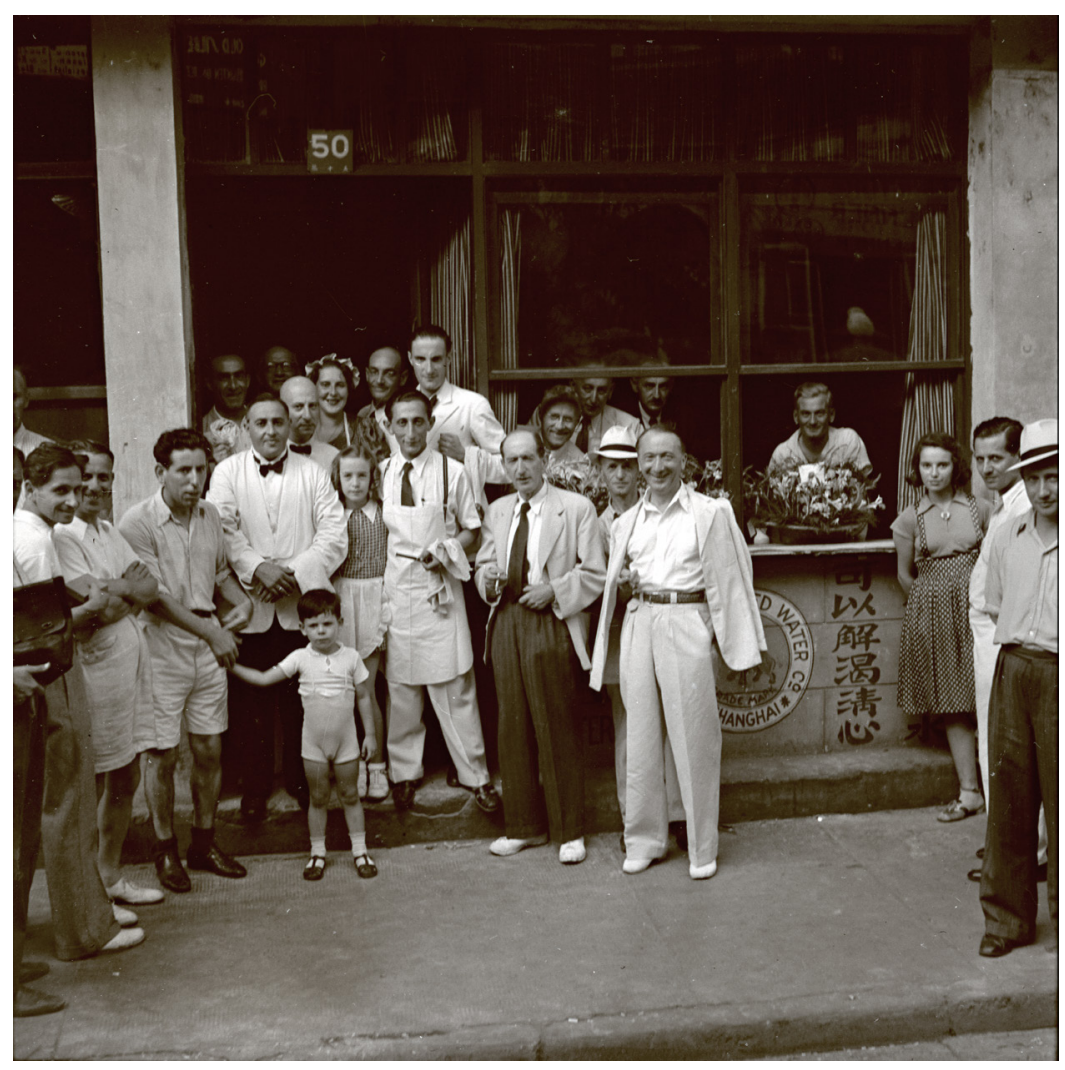

Figure 1. Employees and members of the Jewish refugee community pose in front of Boris Café. Owner Boris Sapiro is in the middle (in apron)

\footnotetext{
${ }^{1}$ See the collection guide: https://oac.cdlib.org/findaid/ark:/13030/c8j968np/?query=werner+von+boltenstern.

${ }^{2}$ In 2014, Erica von Boltenstern visited LMU's Department of Archives of Special Collections to donate some of her father's documents and letters, many of which were from his time in China. During her visit she kindly agreed to be interviewed and shared invaluable biographical information about Werner von Boltenstern.
} 
return to Germany (von Boltenstern 2014). ${ }^{3}$ Heeding her warning, von Boltenstern stayed in China. Based on the dates of his photographs, he most likely arrived in Shanghai in 1937, in time to witness the steady stream of European Jewish refugees entering the port turn into a flood as they fled Germany following the 1938 annexation of Austria and Kristallnacht, which drove thousands of Jews out of Europe. For von Boltenstern, who could find employment in the city and live in the International Settlement, Shanghai was a logical place to live during the war. Indeed, for the approximately 20,000 refugees who fled to the city, Shanghai was a refuge because the government did not require immigrants to have a visa or other documents to enter the port (Ristaino 2001, 12). ${ }^{4}$ That policy became even more crucial when countries like the United States, Great Britain, and Canada slowed or stopped Jewish immigration.

Support for the arriving Jewish refugees was provided by the existing Jewish community in Shanghai, made up of Sephardic Jews, who had begun emigrating from Asian British colonies in the mid-1800s, and Russian Jews, most of whom arrived following the 1917 Russian Revolution, as well as by international Jewish organizations. For those who came with nothing, as was the case for many, housing was made available in a series of refugee camps. The magnitude of the influx inevitably exhausted resources. Refugees lived in overcrowded rooms, where food was often meager, and the substandard housing left them exposed to the region's sweltering summers and freezing winters (Ristaino 2001, 127-129). Yet, despite the hardships, the refugees were safe, at least for a while. Over time, many of them found employment, moved into rented housing, and formed community groups. Some even established businesses. In fact, these positive aspects of refugee life are what von Boltenstern's photographs capture most. Browsing the collection, one finds images of Jewish refugees gathering at Boris Sapiro's café, Jewish community soccer matches, Yiddish theatrical productions, Jewish weddings, and what appears to be the office of the Shanghai Jewish Chronicle, a newspaper founded by refugees and for which von Boltenstern worked as a photographer. ${ }^{5}$

The relative ease with which the refugees entered the city ended in 1942 when the occupying Japanese forces, pressured by their German allies, required all Jewish refugees to register with the Japanese government (Medzini 2016, 76). Persecution of the refugees intensified in 1943, when they were interned in what is often called the "Hongkew ghetto," an area a half-mile long and a three-quarters of a mile wide in the Hongkew part of the International Settlement (Ristaino 2001, 192). To maintain their employment outside the ghetto's walls, refugees had to wait in long lines to get temporary passes from Japanese authorities, an arbitrary process that caused a number of them to lose their jobs. Overcrowding contributed to the spread of illness and, as refugees struggled to maintain employment, hunger and malnutrition became common (Ristaino 2001, 204-205). The Pacific War raging around Hongkew further worsened conditions as the United

\footnotetext{
${ }^{3}$ The von Boltensterns were not Jewish, therefore his mother's warning was not in response to antisemitism.

${ }^{4}$ While documentation was not required to enter Shanghai, it was necessary to leave Europe. As a result, some Jews were prevented from escaping even when they had the means to get to Shanghai.

${ }^{5}$ While conducting a search in the Leo Baeck Institute's Shanghai Jewish Chronicle collection, a number of von Boltenstern's photographs were discovered. See the collection at https://archive.org/details/shanghaijewishch00unse.
} 
States, fighting to end the Japanese occupation, began conducting nightly air raids, dropping thousands of bombs across the city. In 1945, when the Japanese surrendered to the Americans, the refugees were freed, to step out into a world where they would discover, as did everyone else, the horror of the Holocaust and the fate of loved ones left behind.
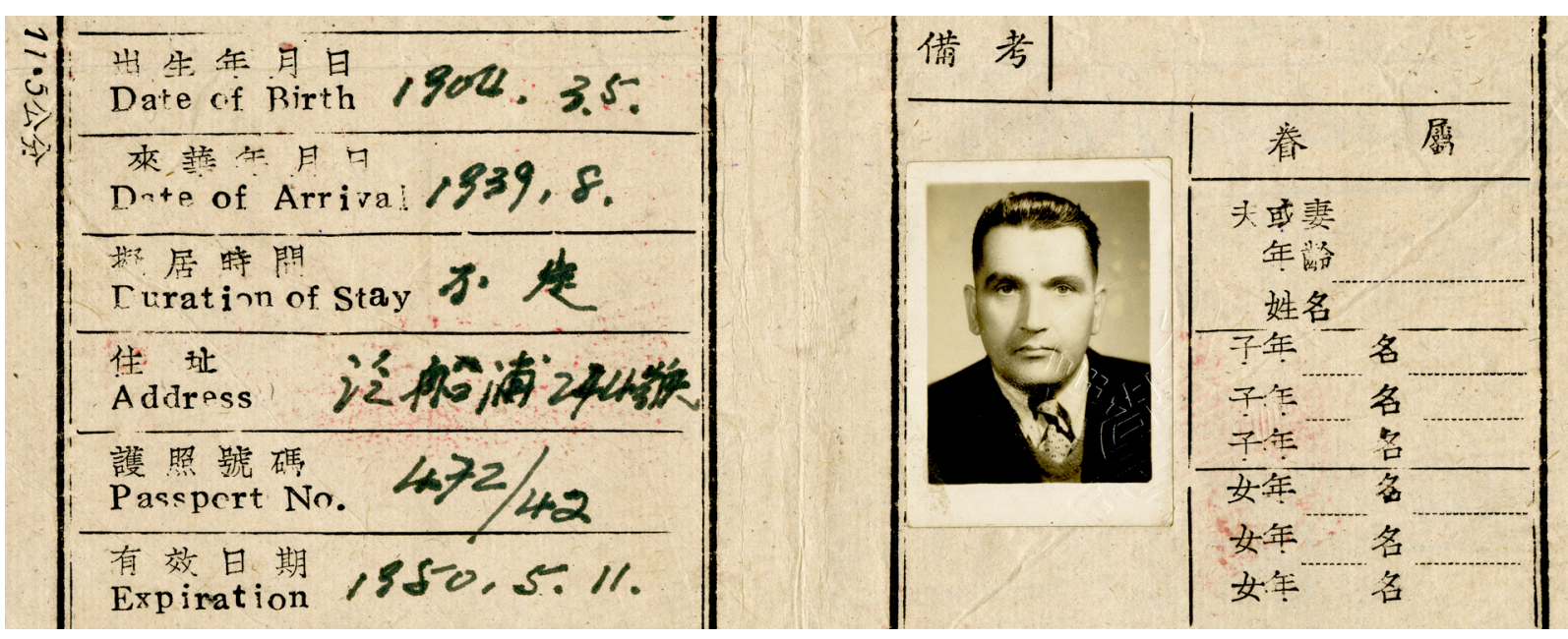

Figure 2. Werner von Boltonstern's Taiwan travel permit

At the end of the war, most Jewish refugees were relocating to places like the United States or returning to Europe. Von Boltenstern remained in China until Mao Zedong's rise to power in the late 1940s forced him out along with other foreigners (von Boltenstern 2014). Though a refugee himself, von Boltenstern discovered that the immigration process was complicated by the fact that he was a German citizen. His passport was no longer officially recognized, and he was suspected of being a Nazi or a Nazi sympathizer. To acquire the necessary immigration documentation, he declared himself stateless and applied for a passport from the Red Cross, a process that required proof that he had no Nazi affiliations (von Boltenstern 2014). To prove his innocence, von Boltenstern had letters written on his behalf and it is through these letters that we gain a sense of his "noble character" (Rahmann 1949). We also gain further insights into his connections with Jewish refugees, which included personal friendships and business relationships (Loewenthal 1946). Dr. S. Sobel attested to von Boltenstern's devotion to the community when he explained that von Boltenstern had financially supported a refugee during his yearlong stay in the hospital (Sobel 1946). The most compelling letter stands out not because of what it says - it is similar in tone and praise to all of the others - but because it was signed by fifteen Jewish refugees (Letter from Fifteen Jewish Refugees, undated). From these letters and through the discovery that von Boltenstern was a photographer for the Shanghai Jewish Chronical, it is clear that he was well integrated into the refugee community. None of this is surprising, considering that many of the refugees were German and that von Boltenstern was a world traveler who was able to move comfortably within different cultural settings. 
With the support of the Jewish refugee community and others who could attest to his good character, von Boltenstern was able to immigrated from China to the United States in the early 1950s. He settled in Los Angeles where he married and had two children. There he continued taking photographs - "he was always taking pictures," his daughter said - and he continued to sell them to postcard publishers (von Boltenstern 2014). Most importantly, von Boltenstern's love of taking photographs for postcards developed into a passion for collecting them, so much so that by the time he donated his collection to LMU, it numbered nearly one million. It was within that vast sea of postcards that the Shanghai Collection was discovered.

\section{The Collection}

The LMU Library digitized the entirety of the Shanghai Collection, which consists of 931 photographic objects: the majority are negatives and about half of those have matching prints. The negatives seem to be limitless in variety. Glass plates and acetate (and possibly nitrate) film are included, in varying sizes and in both sheet and roll form. The digitization team had to experiment with multiple scanner settings, and the condition of the negatives necessitated careful handling. What this painstaking process revealed was remarkable and often unexpected. The box labeled "Shanghai Jewish Community" included photographs of daily life in the Chinese and European communities, sporting events at the College Sainte Jeanne d'Arc, a school located in the French Concession, European businesses throughout the International Settlement, and of cultural events such as Chinese opera. It became clear the Shanghai Collection is a rich resource not only for Holocaust and Jewish studies but for many other areas of scholarship related to midcentury Shanghai.

Metadata creation was as challenging as digitization, for most of the information accompanying the images were simple descriptions like "woman cooking" and "school children," written on the collection's negative and print sleeves. Specific individuals, communities, or locations were rarely identified. For this reason, Rachel Wen-Paloutzian, the librarian who oversaw the metadata creation, had to conduct research, consult with faculty, and examine the images closely in order to describe them in greater detail. That work enabled the library to launch the collection

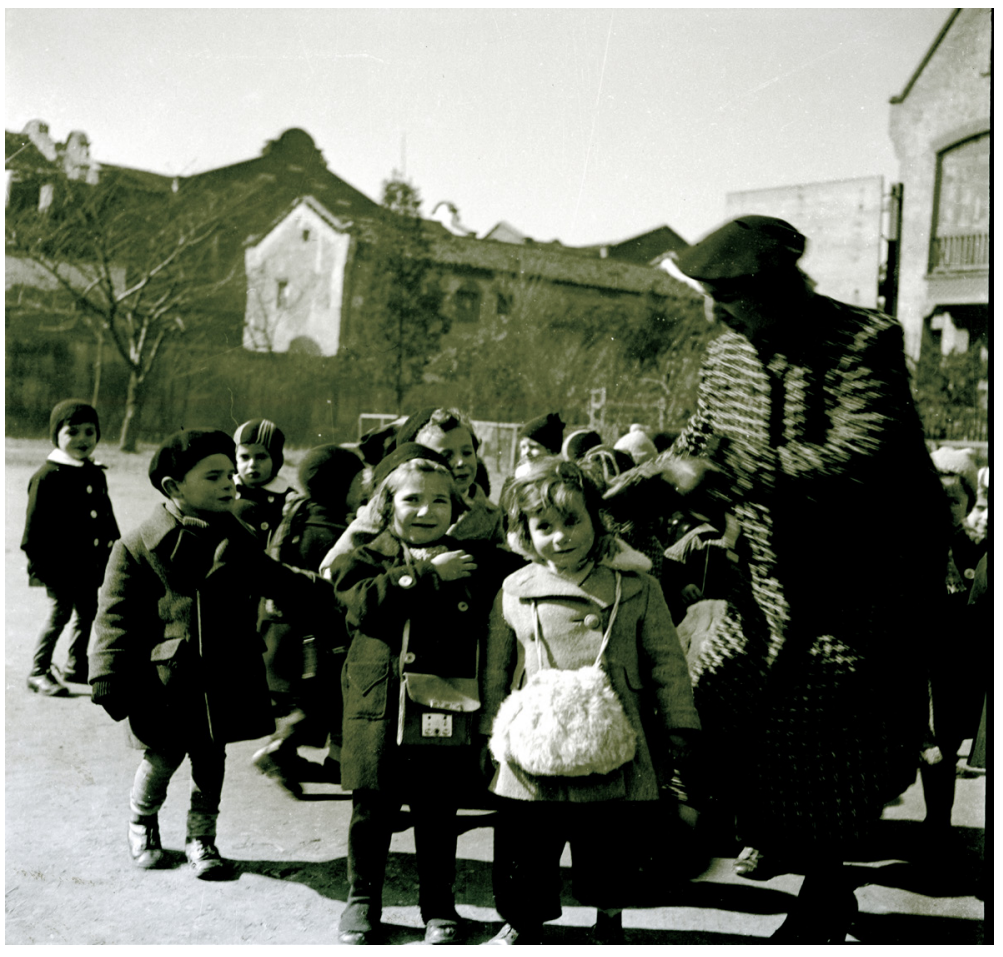

Figure 3. Jewish refugee children attending a kindergarten 
website, which in turn enabled us to seek additional metadata through a crowdsourcing project. Using Twitter and Flickr as well as email, we reached out to a number of institutions and individuals around the world and, within a week, responses began coming in from Australia, France, Germany, Shanghai, Great Britain, Hong Kong, and from across the United States. Such immediate results confirmed the collection's historical value and, for some, its personal value. Contributors provided new information about the images and enhanced or corrected existing metadata. Others simply wanted to share their stories.

Responding to an image of the European Jewish Artist Society soccer team, Henry Haas wrote, "I viewed with great interest the photos, particularly the soccer photo [...]. In the second row the second man on the right is my father Ivan Hans Haas and the baby in the front is me" (personal email to author, August 19, 2015). Gerhardt Moses, a four-year old when he arrived in Shanghai in 1941, contacted us, wanting to know more about the collection and to share his experience. He emphasized the strength of his mother, who stood up to the SS to get the papers necessary to leave Germany for Shanghai, and his gratitude toward the Chinese for welcoming the refu-

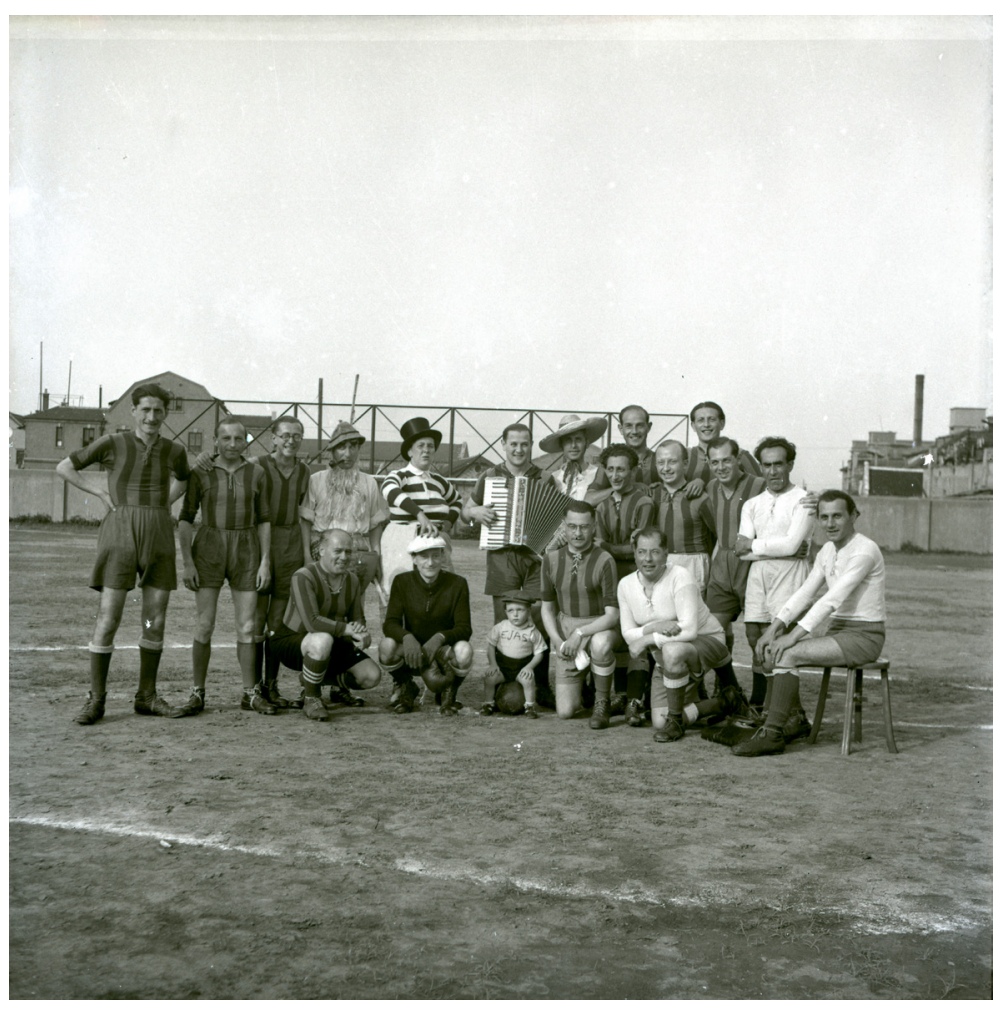

Figure 4. The European Jewish Artist Society soccer team with Henry Haas, his father Ivan Hans Haas, and actors Herbert Zemik, Jenny Rausnitz, and Boris Sapiro gees. Mr. Moses introduced me to Margot Rubenstein (née Rosenzweig), who arrived in Shanghai in 1939 at the age of sixteen. Mrs. Rubenstein's family fled Germany following her father's internment in a camp. When her mother was told he would be released if they could prove they were leaving Europe, she contacted a Jewish organization, which arranged for their travel to Shanghai. Having no means of support when they arrived, the Rosenzweigs were sent to the Chaoufoong Road Heim refugee camp, where they lived until they gained employment and could rent an apartment. Mrs. Rubenstein recalls in detail their arrival in the city and their everyday lives in the camp and in the ghetto. Responses from Mr. Haas, Mr. Moses, Mrs. Rubenstein and others not only provided more information about the photographs and their historical context, they also added humanity to the work we were doing with the collection. 


\section{StUdent ENGAgEMENT}

In spring 2014, just following the launch of the Shanghai Collection website, the LMU Library began promoting the collection for use in undergraduate classes, in particular in history, Jewish studies, and Asian studies courses. Dr. Holli Levitsky, LMU professor of English and director of Jewish Studies, expressed an interest in incorporating the collection into her "Literature of the Holocaust" class. Dr. Levitsky and I led her students through a semester-long assignment, which resulted in the creation of digital projects that illustrate Shanghai Jewish refugee life and culture. Working in groups, students were required to familiarize themselves with the collection, research the history of Jewish refugees in Shanghai, choose a theme represented in von Boltenstern's photographs (e.g., weddings, theater productions, or sports), conduct research focused on that theme, and create their projects using Tumblr. ${ }^{6}$ The project prompted a group of students to correspond with Dr. Steven Hochstadt, professor emeritus of history at Illinois College and author of Exodus to Shanghai: Stories of Escape from the Third Reich (Palgrave Macmillan 2012). ${ }^{7}$ Another group of students interviewed Dr. Yisroel Blumenstein, a Holocaust educator in Los Angeles, whose parents escaped to Shanghai, and they incorporated aspects of his parents' story into their project. At the end of the semester, the students presented their work at a digital poster session open to the LMU community.

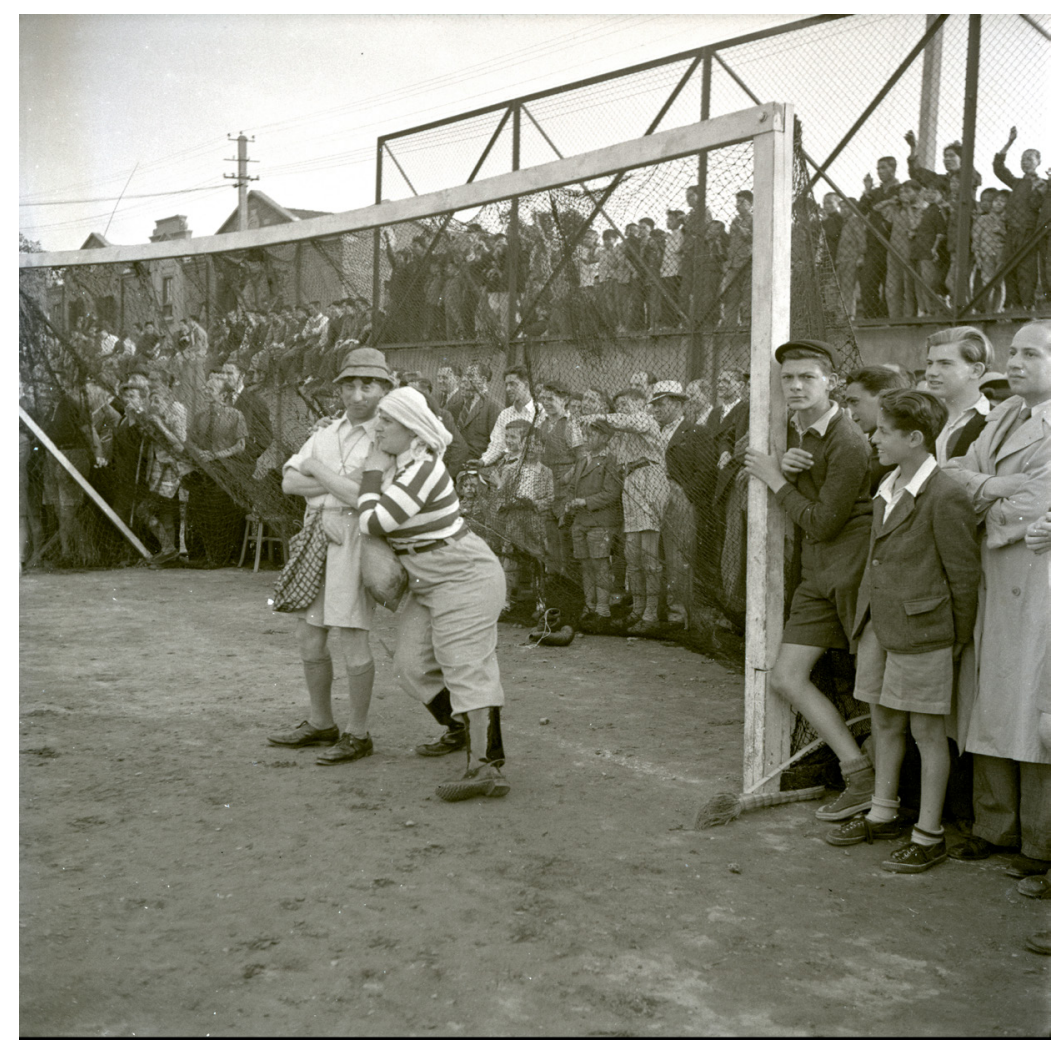

Figure 5. Actress Jenny Rausnitz entertains spectators at a Jewish refugee community soccer match between the European Jewish Artist Society and the Shanghai Jewish Chronicle

The students' projects demonstrate that, given the opportunity, undergraduates can produce thoughtful work that could bring greater awareness to the Shanghai Jewish refugee experience. The students saw things in the Shanghai Collection that librarians had not noticed, for example, the crowd of Chinese spectators in the background of a photograph of a refugee soccer match.

\footnotetext{
${ }^{6} \mathrm{Visit}$ http://dh.lmu.edu/shanghai-project to see student projects and to learn more about the assignment.

${ }^{7}$ Coincidently, Dr. Hochstadt had contributed to the crowdsourcing effort prior to the students contacting him.
} 
Students also identified some notable people and made connections between people and places. As the collection contributed to the students' understanding of the Holocaust, so too did the students contributed to the our understanding of the collection.

\section{CONCLUSION}

Werner von Boltenstern probably did not realize the historical significance of his Shanghai photographs. He filed the photographs together with his postcards and, according to his daughter, he may have even forgotten about them. When asked how her father would feel about the Shanghai Collection's availability online, Ms. von Boltenstern said she believed he would be delighted (von Boltenstern 2014). Von Boltenstern donated his postcard collection to the university because he wanted it to be used for education, a purpose his Shanghai photographs also serve. Making von Boltenstern's photographs digitally available has increased the visual representation of the Shanghai Jewish refugee experience, a lesser-known aspect of Holocaust history.

\section{SOURCES}

Medzini, Meron. 2016. Under the Shadow of the Rising Sun. Boston, MA: Academic Studies Press.

Ristaino, Marcia R. 2001. Port of Last Resort: The Diaspora Communities of Shanghai. Stanford, CA: Stanford University Press.

Von Boltenstern, Erica. 2014. Unpublished interview by Melanie Hubbard and Cynthia Becht, November 17, 2014, William H. Hannon Library, Loyola Marymount University.

\section{Werner von Boltenstern Travel Records Collection, MS119, Department of Archives and Special Collections, William H. Hannon Library, Loyola Marymount University}

Letter from fifteen Jewish residents of Shanghai on behalf of Werner von Boltenstern. n.d. Box lov, Folder 2.

Loewenthal, J.J., 1946. Letter, February 21, 1946. Box 1, Folder 6.

Rahmann, Reverend Rudolph. 1949. Letter, August 26. 1949, Box 1, Folder 6.

Sobel, S. 1946. Letter, February 20, 1946. Box 1, Folder 6. 